\title{
Influence of Brand Equity on Brand Trust: Mediation of Brand Reputation and Moderation of Social Media
}

\author{
Richard Barfi * \\ School of Management, Department of Marketing, Jiangsu University, 301 Xuefu Road, Jingkou District, \\ Zhenjiang, Jiangsu, P.R. China \\ Li Wen Yuan \\ School of Management, Department of Marketing, Jiangsu University, 301 Xuefu Road, Jingkou District, \\ Zhenjiang, Jiangsu, P.R. China \\ Samuel Afryie \\ School of Management, Jiangsu University, 301 Xuefu Road, Jingkou District, \\ Zhenjiang, Jiangsu, P.R. China \\ Brice Berinyuy Fonjong \\ School of Management, Jiangsu University, 301 Xuefu Road, Jingkou District, \\ Zhenjiang, Jiangsu, P.R. China \\ Ran Kwabena Fosu Sarpong \\ School of Management, Jiangsu University, 301 Xuefu Road, Jingkou District, \\ Zhenjiang, Jiangsu, P.R. China
}

\begin{abstract}
The Present study aims to investigate the brand equity of the local as well as international fast food restaurants in the country of Ghana. Furthermore, the study investigates the particular brand association (B Ass.) and brand awareness (B Aw.) dimensions of the brand equity (BE). Moreover, the mediating role of the brand reputation (BR) examined in between dimensions of brand equity and brand trust (BT). In addition the moderating effect of social media also investigated. Study adopted the partial least square 3.0 for inferential statistics as well as structural equation modelling. The results of the study exhibited, that brand equity has positive and significant influence on brand reputation. Moreover the positive and significant effects of social media on brand trust also notified in the study. In addition, the effect of brand awareness on brand trust partially mediated by brand reputation, while the association between brand association and brand trust is fully mediated. Furthermore, the moderating effect of social media (SM) on brand trust noted negative and significant. The outcomes of the scholarship add to advance indulgent of the multifaceted psychosomatic procedures tangled in purchaser selection standards for a fast food restaurants and service industry.

Keywords: Brand Equity (BE); Brand Awareness (B Aw.); Brand Association (B Ass.); Brand Reputation (BR); Brand Trust (BT); Social Media (SM)

DOI: $10.7176 / \mathrm{EJBM} / 11-21-02$

Publication date:July $31^{\text {st }} 2019$

\section{Introduction}

Building and sustaining a brand is indispensable in the current era of modest marketing milieu, and BE is the result of well-planned, and utilized brand activity stashes (Seetharaman et al., 2001). The dimension of BE should precisely assess purchasers' insights of the brand in order to advance marketing approaches that bring into line with consumers' (Cs) morals (Isberg and Pitta, 2013). It's pertinent, not only to customers, buyers, or users, who buy, and use a brand, but also to executives and marketing personnel's, who assess the routine of the particular brand and make influential schemes (Yasin et al., 2007). Hence, the assessment of BE offerings an efficient means to judge both end user brand insights and marketing motion (So and King, 2010).

Vicissitudes in Cs, routines have directed to an upsurge in the plea for diverse eating experiences and to the fast advancements in the fast food restaurant hospitality industry (Min and Min, 2011). Such progress has an impact the exterior of various local and international brands which repeatedly form robust brands in order to fortify keenness and BE so that Cs are capable to identify a particular restaurant (Kim and Kim, 2005). Perkins (2014) proposes that liberated cafes and restaurants putting effort as because the Cs are varying to local restaurants. Hospitality industry of Ghana ranked $4^{\text {th }}$ in African country, especially from profitability point of view (Madison 2019). In addition, (Jumia Travel 2017), exhibited that hospitality especially contributed more into the GDP of the country, it accounted for $7.8 \%$ in 2015 . Furthermore, service sector accounted $56.6 \%$ industry of the country, reports stated that, $28.4 \%$ of population has internet access. Among them (e.g. $82.22 \%$ Facebook, $7.52 \%$ Twitter,
\end{abstract}


7.3\% Pinterest, 1.8\% are YouTube users) (statcounter 2019). In developed countries like U.K.'s eating habits to put orders and doing dining in continue to grow, local food street enjoying more profits than well-known brnads (Angelis, 2013). In 2014, it was supposed to be value roughly ( $£ 16.4$ billion) and current market of chain restaurants predictable to propagate to ( $£ 22$ billion) over the next ten years (Gerrard, 2014). Albeit some scholars have considered the progress of the fast food restaurants, a inadequate number of scholarships emphasis on Cs based BE in the hospitality industry (Hyun and Kim, 2011; Kim and Kim, 2005). Researcher's argument whether $\mathrm{BE}$ dimensions utilized in products marketing can be practical to service-based brands. Owed to the distinctive qualities of services like intangibility and heterogeneity, products-based $\mathrm{BE}$, it is claimed, necessitates alterations to encounter hospitality industry and service brand assessment necessities (Nam et al., 2011).

Furthermore, while preceding studies has evaluated the association amongst BR and BT (Chang, 2013; Park et al., 2014), no scholarship has, to the finest of our knowledge, studied the influence of BR on the association amongst Cs based fast food restaurants and BE and BT in hospitality industry in Ghana. Scholars consider BT as a vital driver in the hospitality sector mostly due to food safety, taste, hygiene and health (Afzal et al., 2010; Song et al., 2012). Moreover, trust is the greatest general extent of brand and consumer link, and may be an important factor BE (Alam and Yasin, 2010). Therefore, Cs habitually select trustworthy eateries grounded on trust. As utmost Cs trust on the eatery's status to surmise quality of food, services, and hygiene, so restaurants devote profoundly in emerging a standing that is reflected reliable (Fandos and Flavian, 2006; Rijswijk and Frewer, 2008). Increasing hunger towards the usage of internet in the country, increasing penetration rate of $16.3 \%$ and $33.6 \%$ of population is using internet (Internet World Stats 2019). It is argued, that consumers not only pay attention to brands via visiting but also spread good as well as bed word of mouth of mouth by using social media. When Cs make selection against the service brands such as eateries, they give higher weightage to risk reduction (Lacey et al., 2009).That is, Cs try to decrease doubt and disquiet by taking into account the overall BE, BT, and BR. Hence, it is vital to investigate advance the associations among BE, BR, BT and moderation of social media in the restaurant industry.

\section{Conceptual Model and Hypothesis Development 2.1 Hypothesis Development;}

A substantial extent of enquiry is rapt towards classifying the measurements of BE and forming a conjoint basis for additional scholarship (Buil et al., 2008; Kumar et al., 2013; Yasin et al., 2007).Aaker(1991) categorized four measurements of BE, specifically, B Aw., B Ass., perceived quality, and brand loyalty. Keeping in view the distinctive qualities of services, scholars have investigated accustomed dimensions of service BE. To investigate the BE of luxury hotels and chain eateries, Kim and Kim (2005) used (e.g. B Aw., brand image, perceived quality, and brand loyalty). Constructing on this, Hyun and Kim (2011) make an addition of the food quality to perceived quality measure in the context of chain restaurant. In the current study, we utilized to measure of their studies B Aw., and B Ass., dimension of BE.

To determine further association to other branding features, the present education further includes BR and BT. BT is "one of the most important characteristics of the chain restaurant brand because it increases consumers' associations with intangible attributes such as taste, reliable hygiene, atmosphere, etc." In the hospitality sector, augmented BT decrease Cs supposed risk when making a choice for a service (Herrera and Blanco, 2011). With concern to this, status is also an appreciated intangible plus of a brand (Dolphin, 2004). In hospitality industry, reputation is mainly critical, given the services' imperceptible character and the difficulty in assessing its quality deprived of having experienced it (Herbig and Milewicz, 1995). Scholars have confirmed that decent reputation is seeming as a signal of trustworthiness (Suh and Houston, 2010) and acts as a forerunner to trust (Alam and Yasin, 2010; Torres-Moraga et al., 2010). Chang (2013) explored the mediation role of trust among "corporate reputation and brand loyalty" in the restaurant industry, and the outcomes buttressed preceding revisions in that "corporate reputation has an influence on trust." Furthermore, Joshi and Yadav (2018), also used the perceived BR as a mediator between brand extensions BE and perceived quality. Thus the present work adopts BR as a mediating variable among BE and BT. While the Sinapuelas and Ho (2019), also proposed the model, in which, he used social connection and trust as an independent variables, and find that social connections has positive influence on giving information. Hence keeping in view the increasing penetration percentages of the internet users we argued that it has significant influence on the trust. 


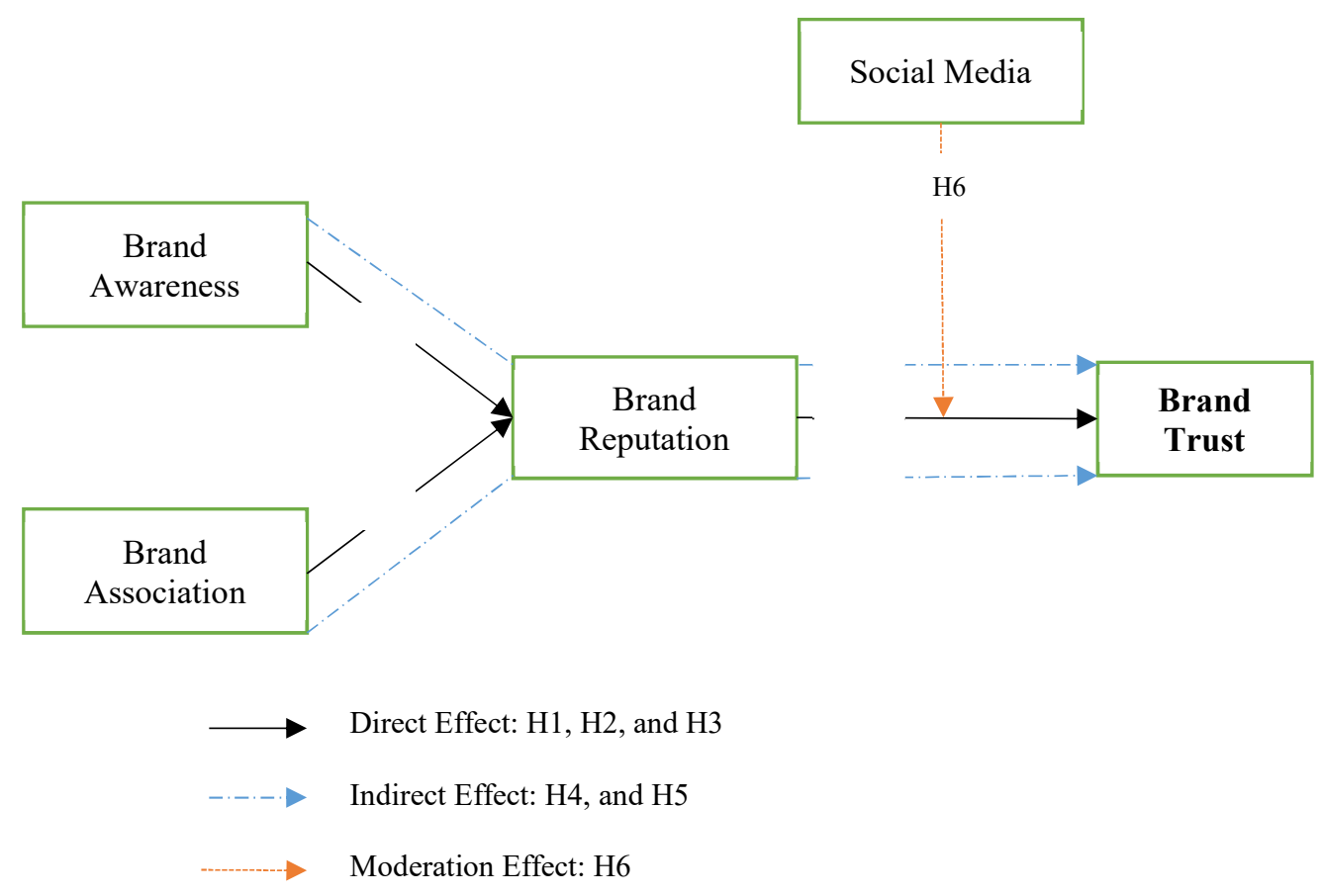

\section{Figure - 1: Conceptual Framework}

Fig.1 represents the conceptual framework of the study. In this study we use Brand awareness and brand association as an independent variable, brand trust as dependent variable, brand reputation as mediator, and social media tools as moderator.

\subsection{Hypothesis Development;}

\subsubsection{The impact of B Ass., on BR}

Keller (1993) defines BR as "the other informational nodes linked to the brand node in memory and contain the meaning of the brand for consumers". The knots comprise particularly facts of a goods and services, such as logos, labeling, price, and advertisement of the particular brand, furthermore, positive or negative toward-of-mouth and the Cs past experience (John et al., 2006). Aaker (1991) states that the basis of BE is the awareness of a brand name which can generate optimistic links for Cs. B Ass., are considered as one of the most critical drivers in building a brand image (Keller, 2008). Positive brand image, in turn, creates a good brand reputation. The formation of a brand image through advertisement, labeling, colors of logos, letters and symbols defines a product/service position, and effectively standing strengthens a robust "brand image" (Pitta and Katsanis, 1995). Romaniuk and Nenycz-Thiel (2013) notified that a resilient memory impact strengthens a brand image. Cs who is devoted to a brand often associate escort with a progressive reputation (Roberts and Dowling, 2002). Hence, the present study hypothesizes that:

\section{$H_{1}$ : B Ass, has a positive and significant impact on BR.}

\subsubsection{The impact of $B$ Aw., on BR}

Brand awareness is "related to the strength of the brand in the minds of consumers, and it enables consumers to recognize and recall the brand, thus enhancing brand equity (Keller, 1993)." B Aw., is a vital goal of marketing efforts in particular organizations, as because "brand image and brand attitude" cannot be shaped in its absenteeism (Macdonald and Sharp, 2003). Some scholars highpoint the vitality of B Aw., in the context of service industry (Kayaman and Arasli, 2007; Krishnan and Hartline, 2001). It is associated with a brand name; it indicates the likelihood that a specific brand name emanates to the Cs mind (Keller, 1993). A brand name helps to decrease the risks of purchasing and using another service brand (Bharadwaj et al., 1993). Mathew et al. (2014) notifies that B Aw., donates to construct sincerity, which in turn, generates trustworthiness intensions. Trust of Cs to a particular brand, thus improves BR. Researchers have confirmed that B Aw., is associated with BR (Maltz, 1991). Both dimensions of brand equity (B Aw., and B Ass,) are reflected to be the core elements of reputation (Davies and Miles, 1998), and hoards in B Aw., can tip to "sustainable competitive advantage and long-term brand value" (Macdonald and Sharp, 2003). Hence, the following the hypothesis constructed.

\subsubsection{The impact of BR on BT}

\section{$\mathrm{H}_{2}$ : $\mathrm{B}$ Aw, has a positive and significant impact on $\mathrm{BR}$.}

Scholars approve that reputation is correlated with attitudes (Schwaiger, 2004). Attitudes are the "feelings and beliefs about a brand on the basis of the knowledge and information obtained from a consumer's experiences" 
(Wright, 2006). Therefore, "a brand's reputation refers to the attitude of consumers that the brand is good and reliable" (Afzal et al., 2010). "Smaǐzien"e (2008) proposes that an optimistic reputation articulates a low level of risk and arouses purchasing decisions. Scholars' acme that trust lessens "uncertainty and risk" (Chaudhuri and Holbrook, 2001). In the service sector, trust is considered a most critical factor in the consumer buying decision (Bredahl, 2001). When Cs trust a brand, they trust that the "food is of high quality, reducing uncertainties like lack of hygiene and freshness." Hence, in preserving an optimistic association amongst Cs and earners, the researchers reflect trust as a vital element (Elliott and Yannopoulou, 2007). BR has the capability to decrease doubt and generate trust ("Smai zien"e, 2008). In the context of a hospitality industry such as fast food and chain restaurants, reputation is considered more influential due to the services' vagueness (Cretu and Brodie, 2007). Investigators have confirmed that BR has an optimistic consequence on BT (Beck and Prügl 2018; Suh and Houston, 2010; Torres Moraga et al., 2010). Reputation thus transports improved trust in the quality of services (Han, Nguyen and Lee, 2015). Thus, the current study hypothesizes that:

\section{$H_{3}: B R$ has a positive and significant impact on $B T$.}

\subsubsection{Mediating effects of Brand Reputation;}

We test the direct impact of BE dimensions on BT to explore the partial and full mediation effects of BR on the association among BE dimensions and BT. Scholars have investigated the link among BT and Cs based BE (Delgado-Ballester and Munuera-Alemán, 2005; Kumar et al., 2013). For instance, Kim (2014) states that humanizing qualities of services are surely connected to refining BT. Hence, by growing food safety standards, quality of food, and the service capability of operating in the eatery, the trust in the brasserie brand is raised (Bredahl, 2001). In addition, Phan and Ghantous (2013) found that B Ass., is the dominant factor of BT in service brands. Furthermore, some scholars used the BR as mediator between BE dimensions and BT and founds the positive outcomes (Han, Nguyen and Lee 2015 and Beck and Prügl 2018). Han, Nguyen and Lee (2015), notified, the positive partial mediation between B Aw., and BT, while, they found the full mediation between B Ass., and BT. Hence, present study hypothesizes that:

\section{$H_{4}$ : The relationship between $B$ Aw., and $B T$ is positively and significantly mediated by $B R$. \\ $H_{5}$ : The relationship between $B$ Aw., and $B T$ is positively and significantly mediated by $B R$. \\ 2.2.5 Moderation of Social Media}

Kaplan and Haenlein, (2010), defined social media as "a group of Internet-based applications that build on the ideological and technological foundations of Web 2.0, and that allow the creation and exchange of User Generated Content." Some of the scholars investigated the effects of social media marketing activities, tools and applications (e.g. Facebook, Twitter, Instagram, and YouTube) on different dimensions of branding (e.g. Brand equity, brand reputation, purchase intension, brand loyalty and brand performance) (Sinapuelas and Ho 2019 and Mishra 2019). In addition, Odoom and Mensah (2018), used social media capabilities moderator and found the significant results of it on brand performance. Likewise, Rebecca VanMeter, et al. (2018), states that Cs recommend brands via social networks to their friends and spreads positive or negative words of mouth. Hence, In the present study, we hypothesized that

\section{H6: $B R * S M$ has signifincat interaction effects on $B T$.}

\section{Methodology}

\subsection{The sample and data collection}

Before going to main conduct of the survey pilot study was conducted with 50 respondents. As because of the time frame, atmosphere and other external factors like education, understandings few of the questions incomprehensible and difficult for respondents to fathom, they were revised. The main survey, led in the major cities of the country (e.g. Accra, Kumasi, Sekondi-Takoradi, and Sunyani. Before proceeding towards filling the questionnaire, respondents were asked do they have any experience of fast food restaurants and brands. The Technique of field survey adopted, specifically convenient random sampling method used. $\mathrm{N}=369$ respondents represent the population of the country. In demographic information, $53.0 \%$ respondents were males, while the rest of $47.0 \%$ were females. $29.0 \%$ of the respondents fall within the age of $16-25$ years. $24.5 \%$ among $26-35,41.5 \%$ in range of $36-45$ and rest of $5.0 \%$ were above 46 years.

\subsection{Measurements}

To assess the constructs (variables), a 7 point-Likert scale used, which range from 1 - strongly disagree to 7 strongly agree. B Aw., measured by using 3 items. B Ass., measured by using 3 items. BR assessed by using 4 items. Construct of BT evaluated by using 5 items. And the social media measured by using 3 items. The items were adopted from previous studies (Han, Nguyen and Lee 2015; Beck and Prügl 2018 and (Mishra 2019).

\section{Findings}

The table -1 : show the results related to the assessment of the constructs. As per rule of thumb set by Nunnally (1978), the coefficient value of CA should be higher than 0.7. In addition, Hinton, Brownlow, McMurray and 
Cozens (2004), standards, there are four categories of CA. Their beliefs that if the value falls in the range of 0.9 or $>$, it will become excellent reliability. If it will fall in between 0.7 to 0.9 it will be named high reliability. If in between 0.5 to 0.7 it will become moderate. And if it will be $<0.5$ it will categorize low. Three constructs results ( $\mathrm{B}$ Ass $=0.748, \mathrm{BR}=0.884$, and $\mathrm{BT}=0.841$ ) fall in the range of 0.7 to 0.9 called excellent reliability. While two constructs outcomes $(\mathrm{B} \mathrm{Aw}=0.614$ and $\mathrm{SM}=0.639$ ) fall in the range of 0.5 to 0.7 which is named moderate. In addition, related to the loading, (Chin W. , 1988), proposed that loadings should have a value greater than 0.5 . Furthermore, (Bagozzi \& Yi, 1988), stated that the value of AVE should be greater than the 0.5. And According to (Gefen, Straub, \& Boudreau, 2000), composite reliability of construct should be greater than 0.7. Hence, keeping in view all the rules of thumbs related to reliability and validity standards, the results of the study founded satisfactory and meet the basic criteria developed by the previous scholars.

\subsection{Table 1: Measurement Model Evolution}

\begin{tabular}{|c|c|c|c|c|c|}
\hline Construct & Items & Loading & $\mathbf{C A}$ & $\mathbf{C R}$ & AVE \\
\hline \multirow{3}{*}{$\begin{array}{l}\text { Brand } \\
\text { awareness } \\
\text { (B Aw.) }\end{array}$} & "I am aware of this brand" & 0.781 & 0.614 & 0.795 & 0.565 \\
\hline & "I am familiar with this restaurant brand" & 0.667 & & & \\
\hline & $\begin{array}{l}\text { "I can recognize this brand among other restaurant } \\
\text { brands" }\end{array}$ & 0.800 & & & \\
\hline \multirow{2}{*}{$\begin{array}{l}\text { Brand } \\
\text { association } \\
\text { (B Ass.) }\end{array}$} & "This brand has an attractive logo" & 0.874 & 0.748 & 0.849 & 0.656 \\
\hline & $\begin{array}{l}\text { "I like the logo of the brand" } \\
\text { "Ilike the colors of building or interior" }\end{array}$ & $\begin{array}{l}0.884 \\
0.648\end{array}$ & & & \\
\hline \multirow{5}{*}{$\begin{array}{l}\text { Brand } \\
\text { reputation } \\
(\mathrm{BR})\end{array}$} & . & & & & \\
\hline & "This brand is trustworthy" & 0.869 & 0.884 & 0.92 & 0.741 \\
\hline & "This brand is reputable" & 0.839 & & & \\
\hline & $\begin{array}{l}\text { "I feel that I have a clear reason to buy this brand } \\
\text { instead of others" }\end{array}$ & 0.875 & & & \\
\hline & "This brand makes honest claims" & 0.861 & & & \\
\hline \multirow{5}{*}{$\begin{array}{l}\text { Brand trust } \\
\text { (BT) }\end{array}$} & $\begin{array}{l}\text { "I can rely on this brand to solve the service } \\
\text { dissatisfaction" }\end{array}$ & 0.821 & 0.841 & 0.888 & 0.614 \\
\hline & "This brand guarantees satisfaction" & 0.659 & & & \\
\hline & "I have confidence in this brand" & 0.758 & & & \\
\hline & "This brands claims are believable" & 0.856 & & & \\
\hline & "This brand delivers what it promises" & 0.809 & & & \\
\hline Social Media & $\begin{array}{l}\text { "I would like to pass information from this brand's } \\
\text { social media to my friends" }\end{array}$ & 0.742 & 0.639 & 0.801 & 0.572 \\
\hline \multirow[t]{2}{*}{ (SM) } & $\begin{array}{l}\text { "It is easy to provide my opinion through this brand's } \\
\text { social media" }\end{array}$ & 0.754 & & & \\
\hline & $\begin{array}{l}\text { "This brand's social media provides customized } \\
\text { service" }\end{array}$ & 0.773 & & & \\
\hline$B R^{*} S M$ & & 0.809 & 1 & 1 & 1 \\
\hline
\end{tabular}

Two methods were used to evaluate the "discriminant validity" of the variables. 1) it was ensured that the cross loadings of indicators should be greater than any other opposing constructs (Joe F Hair et al., 2012). 2) According to the "Fornell and Larcker (1981) criterion, the square root of AVE for each construct should exceed the inter-correlations of the construct with other model constructs" (Table 2). Hence, both approaches ensured the satisfaction of the results and validity.

Table 2: Discriminant Validity Coefficients

\begin{tabular}{|c|c|c|c|c|c|c|}
\hline & B Ass. & B Aw. & $\mathrm{BR}$ & BT & Moderating Effect 1 & SM \\
\hline B Ass. & $0.810 *$ & & & & & \\
\hline B Aw. & 0.803 & $0.752 *$ & & & & \\
\hline $\mathrm{BR}$ & 0.644 & 0.734 & 0.861 * & & & \\
\hline BT & 0.556 & 0.675 & 0.733 & $0.784 *$ & & \\
\hline Moderating Effect 1 & -0.138 & -0.126 & -0.124 & -0.07 & 1 & \\
\hline SM & 0.603 & 0.543 & 0.439 & 0.613 & 0.159 & $0.757 *$ \\
\hline
\end{tabular}

Note: * Bold values represent the square root of average variance extracted (AVE). 
Table 3: Paths Coefficients and Hypothesis Testing

\begin{tabular}{ccccccc}
\hline Hypothesis & Relationship & Path Coefficient & SD & t-value & p-value & Decision \\
\hline Direct Effect & & & & & & \\
& B Ass. - BR & 0.136 & 0.066 & 2.053 & 0.041 & Supported \\
& B Aw. - > BR & 0.623 & 0.060 & 10.365 & 0.000 & Supported \\
& BR - > BT & 0.560 & 0.031 & 18.090 & 0.000 & Supported \\
\hline Indirect Effect & & & & & & \\
& B Ass. -> BR -> BT & 0.076 & 0.036 & 2.103 & 0.036 & Supported \\
& B Aw. -> BR -> BT & 0.349 & 0.044 & 7.938 & 0.000 & Supported \\
\hline Moderating Effect & & & & & & \\
& BR*SM & -0.075 & 0.037 & 2.037 & 0.042 & Supported \\
\hline
\end{tabular}

\section{Discussion and Conclusion}

The current study adds to the mounting literature on BE, BR, BT and the interaction effect of SM. First, this study cores on the progress of a BE model, suitable for chain and fast food restaurant brands (KFC, Pizza Hut, TGI Fridays, Subway, The Chair Bar \& Grill), and emphases on its measurements as embodied by "chain restaurants' consumption psychology". Present study proposes that B Aw., B Ass., are major components of the BE. Although various Scholars have investigated on the advancement of BE framework, there has been less framework in the context of fast food restaurant brands particularly in Ghana. The results shown in table - 3: indicate that B Aw., B Ass., have positive impacts on BR, as well as BR has an optimistic impact on BT. Thus, we confirm the mediating role of BR on the association among BE dimension and BT.

More specifically, we have constructed six hypothesis. From which three comes under the umbrella of direct effect, two under the roof of indirect effect and final hypothesis for moderation effect. Hypothesis - 1: stated that B Ass., has positive and significant influence on BR. Results mentioned in the table -3 : reveals positive beta coefficient 0.136 , standard deviation 0.066 , t-value $2.053>1.96$, p-value $0.041<0.05$, decision supported the hypothesis. Hence the results are consistent with previous studies (Romaniuk and Nenycz-Thiel 2013, and Han, Nguyen and Lee 2015). Hypothesis - 2: stated that B Aw., has positive and significant influence on BR. Results mentioned in the table -3 : reveals positive beta coefficient 0.623 , standard deviation 0.060 , t-value $10.365>1.96$, p-value $0.000<0.05$, decision supported the hypothesis, results of the study supported by previous work of (Han, Nguyen and Lee 2015; and Mathew et al. 2014). In addition hypothesis - 3: constructed for the positive and significant impact of BR on BT. 0.560 beta coefficient, 0.031 standard deviation, $18.090>1.96 \mathrm{t}$-value and 0.000 $<0.05 \mathrm{p}$-value founded. All the results founded to support the hypothesis made, and results also alike to the previous investigation (Beck and Prügl 2018; Suh and Houston, 2010; Torres Moraga et al., 2010). Hypothesis - 4 \& 5: established in support of mediating effect of BR towards BT, the results founded positive and significant as t-value 2.103 and $7.938>2$ and $p$-value 0.036 and $0.000<0.05$. The results noted also supported by previous studies Han, Nguyen and Lee 2015 and Beck and Prügl 2018). Furthermore, the hypothesis - 6: established for moderating effect of social media, results founded with negative path coefficient -0.075 , standard deviation 0.037 , $t$-value $2.037>1.96$ and p-value $0.042<0.05$. However, a hypothesis supported as because the results are significant. The result is consistent with previous studies of (Rebecca VanMeter, et al. 2018). In conclusion, it is indispensable to understand the drive of stopover and advance BE dimensions grounded on the aims of the visit in the hospitality industry to improve the reputation and trust of service providing organizations. Furthermore, executives should habitually crisscross whether Cs are satisfied with restaurant, and alter it consequently grounded on social inclinations and target Cs penchants.

\section{Limitation and Future Direction}

This study was conducted in a context of Ghana. In addition, it focused only on major brands and is served in the hospitality industry. Field survey only conducted in major cities of the country. Furthermore, only two dimensions of the brand equity considered. Hence, future studies needed to involve other dimensions of the brand equity (e.g. brand affect, self-congruence, food and service quality). Furthermore, this study can be applied to other industry/sectors. This study can carry forward the study effects of brand equity dimension on brand performance. Furthermore, the interaction effect of social media needed to be explored on branding. Marketing heads required to focus on the qualities of the foods and services, ambiance, staff grooming and use of languages as it's prone to the establishment of trust and reputation of the brand and restaurant (Johnson and Grayson, 2005). In addition, According to Grisaffe and Nguyen (2011), "superior quality, effective advertising, service excellence, emotional memories, identity construction, self-expression, and socialization can evoke emotional attachment." Marketing executives should contemplate how to arouse Cs sensitive attitudes based on their demographics (e.g. age, gender, and education) and other driver's like trust, goals and an environment. For instance, the atmosphere of service providing companies (e.g. lighting, color, layouts, and music) needs to be considered as per Cs symbolic necessities. 


\section{References}

Aaker, D.A., 1991. Managing Brand Equity: Capitalizing on the Value of a Brand Name. The Free Press, New York.

Afzal, H., Khan, M.A., Rehman, K., Ali, I., Wajahat, S., 2010. Consumer trust in the brand: can it be built through brand reputation, brand competence and brand predictability. Int. Bus. Res. 3 (1), 43-49.

Alam, S.S., Yasin, N.M., 2010. The antecedents of online brand trust: Malaysian evidence. J. Bus. Econ. Manage. $11(2), 210-226$

Angelis, A.D., 2013. UK restaurant industry. Retrieved from https://uk.finance. yahoo.com/news/uk-restaurantindustry

Beck, S, and R. Prügl. 2018. "Family Firm Reputation and Humanization: Consumers and the Trust Advantage of Family Firms Under Different Conditions of Brand Familiarity." Family Business Review 1-23.

Bharadwaj, S.G., Varadarajan, P.R., Fahy, J., 1993. Sustainable competitive advantage in service industries: a conceptual model and research propositions. J. Market. 57, 83-99.

Bredahl, L., 2001. Determinants of consumer attitudes and purchase intentions with regard to genetically modified foods: results of a cross-national survey. J. Consum. Pol. 24 (1), 23-61.

Buil, I., Chernatony de, L., Martinez, E., 2008. A cross-national validation of the consumer-based equity scale. J. Prod. Brand Manage. 17 (6), 384-392.

Chang, K.-C., 2013. How reputation creates loyalty in the restaurant sector. Int. J. Contemp. Hosp. Manage. 25 (4), 536-557.

Chaudhuri, A., Holbrook, M.B., 2001. The chain of effects from brand trust and brand affect to brand performance: the role of brand loyalty. J. Market. 65 (2), 81-93.

Chin, W. (1988). The partial least squares approach to structural equation modeling. Modern Methods for Business Research, 295(2), 295-336.

Cretu, A.E., Brodie, R.J., 2007. The influence of brand image and company reputation where manufacturers market to small firms: a customer value perspective. Ind. Market. Manage. 36, 230-240.

Davies, G., Miles, L., 1998. Reputation management: theory versus practice. Corp. Reput. Rev. 2 (1), 16-27.

Delgado-Ballester, E., Munuera-Alemán, J.L., 2005. Does brand trust matter to brand equity? J. Prod. Brand Manage. 14 (3), 187-196.

Dolphin, R.R., 2004. Corporate reputation-value creating strategy. Corp. Govern. 4 (3), 77-92.

Elliott, R., Yannopoulou, N., 2007. The nature of trust in brands: a psychosocial model. Eur. J. Market. 41 (9/10), 988-998.

Fandos, C., Flavian, C., 2006. Intrinsic and extrinsic quality attributes, loyalty and buying intention: analysis for a PDO product. Br. Food J. 108 (8), 646-662.

Fornell, C., \& Larcker, F. (1981). Evaluating Structural Equation Models with Unobservable Variables and Measurement Error. Journal of Marketing Research, 39-50.

Gefen, D., Straub, D., \& Boudreau, M. (2000). Structural Equation Modeling and Regression Guidelines for Research Practice. Communications of the Association for Information Systems, 4(7), 1-77.

Gerrard, N., (2014). Restaurant \& casual dining insight report. Retrieved from www.thecaterer.com

Grisaffe, D.B., Nguyen, H.P., 2011. Antecedents of emotional attachment to brands. J. Bus. Res. 64, 1052-1059.

Han, S.H, B Nguyen, and T.J. Lee. 2015. "Consumer-based chain restaurant brand equity, brand reputation, and brand trust." International Journal of Hospitality Management 50 (2015): 84-93.

Herbig, P., Milewicz, J., 1995. The relationship of reputation and credibility to brand success. J. Consum. Market. $12(4), 5-10$.

Herrera, C.F., Blanco, C.F., 2011. Consequences of consumer trust in PDO food products: the role of familiarity. J. Prod. Brand Manage. 20 (4), 282-296.

Hinton, P., Brownlow, C., McMurray, I., \& Cozens, B. (2004). . (2004). SPSS Explained. : . : . East Sussex, England: Routledge Inc.

Hyun, S.S., Kim, W., 2011. Dimensions of brand equity in the chain restaurant industry. Cornell Hosp. Quart. 52 (4), 429-437.

Internet World Stats . 2019. AFRICA. https://www.internetworldstats.com/africa.htm.

Isberg, S., Pitta, D., 2013. Using financial analysis to assess brand equity. J. Prod. Brand Manage. 22 (1), 65-78.

John, D.R., Loken, B., Kim, K., Monga, A.B., 2006. Brand concept maps: a methodology for identifying brand association networks. J. Market. Res. 43, 549-563.

Johnson, D., Grayson, K., 2005. Cognitive and affective trust in service relationships. J. Bus. Res. 58 (4), 500 507.

Joshi, R, and R. Yadav. 2018. "Exploring the Mediating Effect of Parent Brand Reputation on Brand Equity." Paradigm 22 (2): 1-18.

Jumia Travel. 2017. Hospitality Report Ghana. https://travel.jumia.com/en-gb/hospitality-report-ghana.

Kaplan, A.M. and Haenlein, M. (2010), "Users of the world, unite! The challenges and opportunities of Social 
Media”, Business Horizons, Vol. 53 No. 1, pp. 59-68,

Kayaman, R., Arasli, H., 2007. Customer based brand equity: evidence from the hotel industry. Manag. Ser. Quality 17 (1), 92-109.

Keller, K.L., 1993. Conceptualizing, measuring, and managing customer-based brand equity. J. Market. 57 (1), 1 22.

Keller, K.L., 2008. Strategic Brand Management: Building, Measuring, and Managing Brand Equity. Pearson/Prentice Hall, Upper Saddle River, NJ.

Kim, H., Kim, W.G., 2005. The relationship between brand equity and firms' performance in luxury hotels and chain restaurants. Tour. Manage. 26 (4), 549-560.

Krishnan, B.C., Hartline, M.D., 2001. Brand equity: is it more important in services? J. Ser. Market. 15 (5), 328 342.

Kumar, R.S., Dash, S., Purwar, P.C., 2013. The nature and antecedents of brand equity and its dimensions. Market. Intell. Plann. 31 (2), 141-159.

Lacey, S., Bruwer, J., Li, E., 2009. The role of perceived risk in wine purchase decisions in restaurants. Int. J. Wine Bus. Res. 21 (2), 99-117.

Macdonald, E., Sharp, B., 2003. Management perceptions of the importance of brand awareness as an indication of advertising effectiveness. Market. Bull. 14 (2), 1-11.

Madison, E. 2019. Hospitality Industry in Ghana. https://study.com/academy/lesson/hospitality-industry-inghana.html.

Maltz, E., 1991. Managing Brand Equity: A Conference Summary. Marketing Science Institute, Cambridge, MA, Report, 99-110.

Mathew, V., Ali, R.T.M., Thomas, S., 2014. Loyalty intentions: Does the effect of commitment, credibility and awareness vary across consumers with low and high involvement? J. Indian Bus. Res 6 (3), 213-230.

Min, H., Min, H., 2011. Benchmarking the service quality of fast-food restaurant franchises in the USA. A longitudinal study. Benchmark.: An Int. J. 18 (2), 282-300.

Mishra, A.S. 2019. "Antecedents of consumers' engagement with brand-related content on social media." Marketing Intelligence \& Planning 1-16.

Nam, J., Ekinci, Y., Whyatt, G., 2011. Brand equity, brand loyalty and consumer satisfaction. Ann. Tourism Res. 38 (3), 1009-1030.

Nunnally, J. (1978). Psychometric Theory. New York: McGraw-Hill.

Odoom, R, and P. Mensah. 2018. "Brand orientation and brand performance in SMEs: The moderating effects of social media and innovation capabilities ." Management Research Review 1-18.

Park, J., Lee, H., Kim, C., 2014. Corporate social responsibilities, consumer trust and corporate reputation: South Korean consumers'perspectives. J. Bus. Res. 67 (3), 295-302.

Perkins C., (2014). Independent restaurants could suffer as eating out market grows. Retrieved from http://www.bighospitalty.co.uk/Venues

Pitta, D.A., Katsanis, L.P., 1995. Understanding brand equity for successful brand extension. J. Consum. Market. $12(4), 51-64$.

Rebecca VanMeter, R, H.A Syrdal, S.M Mantel, D.B Grisaffe, and E.T. Nesson. 2018. "Don't Just "Like" Me, Promote Me: How Attachment and Attitude Influence Brand Related Behaviors on Social Media." Journal of Interactive Marketing 43 (2018): 83-97.

Rijswijk, W., Frewer, L.J., 2008. Consumer perceptions of food quality and safety and their relation to traceability. British Food J. 110 (10), 1034-1046.

Roberts, P.W., Dowling, G.R., 2002. Corporate reputation and sustained superior financial performance. Strategic Manage. J. 23 (12), 1077-1093.

Romaniuk, J., Nenycz-Thiel, M., 2013. Behavioral brand loyalty and consumer brand associations. J. Bus. Res. $66,67-72$.

Schwaiger, M., 2004. Components and parameters of corporate reputation: an empirical study. Schmalenbach Bus. Rev. 56, 46-71.

Seetharaman, A., Nadzir, Z.A.B.M., Gunalan, S., 2001. A conceptual study on brand valuation. J. Prod. Brand Manage. 10 (4), 243-256.

Sinapuelas, I.C, and F.H. Ho. 2019. "Information exchange in social networks for health care ." Journal of Consumer Marketing 1-12.

Smai zien e, I., 2008. Revealing the value of corporate reputation for increasing competitiveness. Econ. Manage. $13,718-723$.

So, K.K.F., King, C., 2010. When experience matters: building and measuring hotel brand equity. Int. J. Contemp. Hosp. Manage. 22 (5), 589-608.

Song, Y., Hur, W.M., Kim, M., 2012. Brand trust and affect in the luxury brand-customer relationship. Soc. Behav. Personal. 40 (2), 331-338. 
statcounter. 2019. Social Media Stats Ghana. Aril. http:/gs.statcounter.com/social-media-stats/all/ghana.

Suh, T., Houston, M.B., 2010. Distinguishing supplier reputation from trust in buyer-supplier relationships. Ind. Market. Manage. 39 (5), 744-751.

Torres-Moraga, E., Vásquez-Parraga, A.Z., Barra, C., 2010. Antecedents of donor trust in an emerging charity sector: the role of reputation, familiarity, opportunism and communication. Transylvanian Rev. Admin. Sci. 29, 159-177.

Wright, R., 2006. Consumer Behviour. Thomson, London.

Yasin, N.M., Noor, M.N., Mohamad, O., 2007. Does image of country-of-origin matter to brand equity? J. Prod. Brand Manage. 16 (1), 38-48. 